\title{
PENERAPAN PENDEKATAN MATEMATIKA REALISTIK UNTUK MENINGKATKAN KEMAMPUAN REPRESENTASI MATEMATIS SISWA
}

\author{
Misel, Erna Suwangsih \\ Universitas Pendidikan Indonesia \\ Kampus Purwakarta
}

\begin{abstract}
Abstrak
Kemampuan representasi matematis yang dimiliki siswa kelas IV SDN 17 Nagri Kaler masih tergolong rendah. Hal itu disebabkan karena dalam proses pembelajaran matematika yang diterapkan di SDN 17 Nagri Kaler masih bersifat konvensional, yaitu pemberian materi langsung pada tahap simbolik, pemberian contoh-contoh serta soal latihan, menyebabkan siswa cenderung menghafal materi dan bekerja secara procedural. Penelitian ini bertujuan untuk: (1) mendeskripsikan langkah-langkah pembelajaran matematika realistik dalam pembelajaran materi pokok pecahan untuk siswa kelas IV SDN 17 Nagri Kaler tahun pelajaran 2014/2015, (2) mengetahui peningkatan kemampuan representasi siswa kelas IV SDN 17 Nagri Kaler tahun pelajaran 2014/2015 tentang materi pokok pecahan melalui pembelajaran matematika realistik. Penelitian ini adalah penelitian tindakan kelas yang dilaksanakan pada siswa kelas IV SDN 17 Nagri Kaler Purwakarta. Berdasarkan data hasil penelitian dapat disimpulkan bahwa penerapan pendekatan matematika realistik dalam pembelajaran dapat meningkatkan kemampuan representasi matematis siswa dan aktivitas siswa kelas IV di IV SDN 17 Nagri Kaler.
\end{abstract}

Kata Kunci: Pendekatan matematika realistik, kemampuan representasi matematik

\section{A. Pendahuluan}

Matematika merupakan ilmu dasar yang mempunyai peranan penting dalam perkembangan ilmu pengetahuan di sekolah memandang matematika sebagai bidang studi yang paling sulit. Padahal matematika merupakan mata pelajaran yang banyak berguna dalam kehidupan.Matematika merupakan sarana berpikir logis untuk memecahkan masalah dalam kehidupan sehari-hari.

National Council of Teachers of Mathematics (NCTM) 2000 menyatakan bahwa dalam pelaksanaan pembelajaran matematika di sekolah, guru harus memperhatikan lima kemampuan matematis, yaitu: kemampuan pemecahan masalah, penalaran, komunikasi, koneksi, dan representasi. Lebih spesifik lagi, NCTM (2000, hlm 208) menegaskan bahwa kemampuan representasi matematis sangat penting untuk dimiliki siswa sebagaimana diungkapkan dibawah ini:
Representation is central to the study of mathematics. Students can develop and deepen their understanding of mathematical concepts and relationships as they create, compare, and use various representations. Representations also help students communicate their thinking.

Berdasarkan uraian tersebut, kemampua representasi merupakan salah satu kemampuan yang penting untuk dikembangkan dah harus dimiliki oleh siswa.Kemampuan representasi merupakan pusat dari studi matematika sehingga siswa dapat membangun dan memperdalam konsep pemahaman matematis dan hubungannya dengan membuat, membandingkan, dan menggunakan representasi yang bermacam-macam.Representasi juga membantu mengkomunikasikan pemikiran siswa tentang matematika. Kemampuan representasi matematis siswa perlu dikembangkan melalui proses dengan mempertimbangkan 
tahap perkembangan khususnya bagi siswa sekolah dsar yang sedang memasuki fase operasional konkret.

Pada kenyataannya yang terjadi di SDN 17 Nagri Kaler, berdasarkan hasil data awal menunjukkan kemampuan representasi matematis siswa masih tergolong rendah, kategori lulus hanya diperoleh 9 orang siswa (23.7\%), sedangkan 29 orang siswa (76.3\%) dinyatakan masih belum lulus. Sedangkan rata-rata kelas yang diperoleh berada dalam kategori kurang yaitu sebesar 50.32.

Kemampuan representasi adalah salah satu standar proses pembelajaran matematika yang perlu ditumbuhkan dan dimiliki siswa. Standar proses ini hendaknya disampaikan tidak secara terpisah dengan materi matematika. Sayang sekali, representasi sering diajarkan dan dipelajari seolah-olah berdiri sendiri tanpa ada kaitan dalam matematika (Depdiknas, 2005, hlm. 51).Oleh karena itu, untuk memperbaiki keadaan yang demikian perlu upaya dari guru selaku pendidik untuk menciptakan situasi belajar yang mampu meningkatkan kemampuan matematis, khususnya kemampuan representasi serta menciptakan situasi belajar yang mampu membuat siswa memberikan respon positif.Salah satu upaya untuk meningkatkan kemampuan representasi yaitu dengan menentukan suatu pendekatan pembelajaran yang mengutamakan keaktifan pada diri siswa sehingga mampu mengeksplorasi kemampuan berfikir siswa.Ditinjau dari perubahan kurikulum yang saat ini sedang diberlakukan pendekatan matematika realistik merupakan salah satu pendekatan pembelajaran yang sesuai dengan perubahan tersebut. Pendekatan matematika realistik dikembangkan berdasarkan pandangan Freudenthal yang berpendapat bahwa matematika merupakan kegiatan manusia yang lebih menekankan aktivitas siswa untuk mencari, menemukan, dan membangun sendiri pengetahuan yang diperlukan sehingga pembelajaran menjadi terpusat pada siswa.

Dengan menggunakan pendekatan matematika realistik ini diharapkan kemampuan representasi matematis siswa dapat ditingkatkan karena prinsip utama pendekatan ini adalah siswa harus berpartisipasi secara aktif dalam proses belajar. Siswa harus diberi kesempatan untuk membangun pengetahuan dan pemahaman mereka sendiri. Guru tidak lagi memaksakan siswa untuk mengikuti cara berpikir yang dimilikinya, tetapi harus memberi kesempatan kepada siswa untuk mengembangkan cara berfikir mereka sesuai dengan potensinya, dan guru hanya berperan membantu serta mengarahkan cara berfikir siswa untuk memahami konsep melalui pertanyaan arahan (bukan memberikan secara langsung).

\section{B. Kajian Teoritik}

\section{Pengertian Matematika Realistik \\ Pendekatan}

Ada berbagai macam pendekatanpendekatan dalam pengajaran, khususnya pengajaran matematika Realistic Mathematics Education adalah sebuah pendekatan belajar yang dikembangkan sejak tahun 1971 oleh sekelompok ahli matematika dari Freudenthal Institute, Utrecht University di Negeri Belanda. Pendekatan Matematika Realistik adalah suatu teori pembelajaran yang dikembangkan khusus untuk mata pelajaran matematika.Pendekatan Matematika Realistik (yang selanjutnya disebut PMR) di Indonesia mulai dikenalkan pada tahun 2001 dibeberapa perguruan tinggi secara kolaboratif melalui proyek pendekatan matematika realistik di sekolah dasar.

Dalam Pendekatan Matematika Realistik (PMR) bertolak dari masalahmasalah kontekstual, siswa berperan aktif dalam pembelajaran, guru berperan sebagai fasilitator, siswa bebas mengeluarkan idenya, siswa berbagi ide-idenya, siswa dengan bebas mengkomunikasikan ide-idenya 
satu sama lain. selanjutnya, guru membantu membandingkan ide-ide tersebut dan membimbing siswa mengambil kesempatan tentang ide terbaik untuk mereka (Suryadi, 2002, hlm. 43).

Sejalan dengan pendapat di atas, Gravermeijer (1994, hlm. 91) mengemukakan bahwa PMR merupakan sebuah pendekatan yang berdasarkan konsep Freudenthal yang mengatakan bahwamatematika merupakan aktivitas manusia.Dengan ide utamanya adalah bahwa siswa harus diberi kesempatan untuk menemukan kembali (reinvent) ide dan konsep matematika tersebut melalui penjelajahan berbagai situasi dan masalah-masalah realistik.Pengertian realistik dalam hal ini tidak hanya situasi yang ada di dunia nyata, tetapi juga dengan masalah yang dapat mereka bayangkan.

Pendekatan matematika realistik merupakan salah satu pendekatan pembelajaran matematika yang berorientasi pada siswa, bahwa matematika adalah aktivitas manusia dan dan matematika harus dihubungkan secara nyata terhadap konteks kehidupan sehari-hari siswa ke pengalaman belajar yang berorientasi pada hal-hal yang real (nyata) (Susanto, 2013, hlm. 205).

Berdasarkan beberapa penjelasan definisi PMR di atas, maka dalam hal ini PMR merupakan suatu proses pembelajaran yang holistic dan bertujuan membantu siswa untuk memahami makna suatu materi pelajaran dengan konteks kehidupan sehari-hari melalui tahap-tahap pembelajaran pemberian masalah kontekstual, pemodelan, sehingga siswa memiliki pengetahuan dan keterampilan yang secara fleksibel dapat diharapkan di kehidupan sehariharinya.

Adapun karakteristik PMR adalah sebagai berikut:

Sedangkan menurut Gravemeijer (1994, hlm. 114 - 115), PMR memiliki beberapa karakteristik, yaitu: a) the use of context, b) the use of models,bridging by vertical instrument, c) student contribution, d) interactivity dan e) intertwining. Penjelasan dari kelima karakteristik tersebut, secara singkat sebagai berikut:

a. Penggunaan masalah kontekstual (the use of context)

Proses pembelajaran diawali dengan keterlibatan siswa dalam pemecahan masalah kontekstual.

b. Digunakan model atau jembatan dengan Instrument vertical (the use of models, bridging by vertical instrument)

Konsep atau ide metematika direkonstruksikan oleh siswa melalui model-model instrument vertikal yang bergerak dari prosedur informasi ke bentuk formal.

c. Digunakannya produksi dan konstruksi oleh siswa (student contribution)

Siswa aktif mengkonstruksi sendiri bahan matematika berdasarkan fasilitas dengan lingkungan belajar yang disediakan guru secara aktif,menyelesaikan soal dengan cara masing-masing.

d. Adanya interaktivitas (interactivity)

Bentuk-bentuk interaksi yang berupa negosiasi, penjelasan, pembenaran, persetujuan, ketidak setujuan, pertanyaan atau refleksi, digunakan untuk mencapai bentuk formal dari bentuk-bentuk informal yang diperoleh siswa.

e. Adanya Keterkaitan antara beberapa bagian dari materi pembelajaran (intertwining)

Pembelajaran bahan matematika terkait dengan berbagai topik matematika secara terintegritas.

Mendesain pembelajaran dengan Pendekatan Matematika Realistik mengacu pada prinsip dan karakteristik PMR, maka langkah-langkah pembelajaran matematika realistik yang akan diterapkan dalam penelitian ini mengacu pada pendapat Shoimin (2013, hlm. 150-151), namunada 
penambahan pada langkah ke-2 yaitu langkah menjelaskan masalah kontekstual, untuk lebih rincinya adalah sebagai berikut:

Langkah 1.Memahami masalah kontekstual.Pada langkah ini, guru menyajikan masalah kontekstual kepada siswa.Selanjutnya guru meminta siswa untuk memahami masalah itu terlebih dahulu.

Langkah 2.Menjelaskan masalah kontekstual.Langkah ini ditempuh saat siswa mengalami kesulitan memahami masalah kontekstual.Pada langkah ini, guru memberikan bantuan dengan memberi petunjuk atau pertanyaan seperlunya yang dapat mengarahkan siswa untuk memahami masalah.

Langkah 3.Menyelesaikan masalah kontekstual.Pada tahap ini, siswa didorong menyelesaikan masalah kontekstual secara individual berdasarkan kemampuannya dengan memanfaatkan petunjuk-petunjuk yang telah disediakan.Siswa mempunyai kebebasan menggunakan caranya sendiri. Dalam proses memecahkan masalah, sesungguhnya siswa dipancing atau diarahkan untuk berfikir menemukan atau menkonstruksi pengetahuan untuk dirinya. Pada tahap ini, dimungkinkan bagi guru untuk memberikan bantuan seperlunya (scaffolding) kepada siswa yang benarbenar memerlukan bantuan.

Langkah 4.Membandingkan dan mendiskusikan jawaban.Guru meminta siswa untuk membandingkan dan mendiskusikan jawaban yang dimilikinya dalam diskusi kela. Pada tahap ini guru menunjuk atau memberikan kesempatan kepada pasangan siswa untuk mengemukakan jawaban yang dimilikinya ke muka kelas dan mendorong siswa yang lain untuk mencermati dan menanggapi jawaban yang muncul di muka kelas.

Langkah 5.Menyimpulkan dari hasil diskusi kelas.Guru mengarahkan siswa untuk menarik kesimpulan mengenai pemecahan masalah, konsep, prosedur atau prinsip yang telah dibangun bersama.

\section{Kemampuan} Matematik

Representasi

Konsep representasi merupakan salah satu konsep psikologis yang sering digunakan dalam bidang pendidikan matematika untuk menjelaskan beberapa fenomena penting tentang cara berfikir anak-anak.

Selanjutnya, dalam psikologi matematika representasi didefinisikan sebagai deskripsi hubungan antara obyek dan simbol (Hwang, dkk, 2007). Representasi adalah konfigurasi yang dapat mewakili sesuatu hal tertentu dalam beberapa cara lainnya (suatu konfigurasi yang dapat menggambarkan sesuatu objek dalam beberapa cara)(Putri, 2013, hlm. 35)

Pendapat ahli lain mengemukakan bahwa representasi adalah suatu proses yang melambangkan atau menyimbolkan suatu obyek (benda) (Rosengrant, dkk, 2007). Lambang atau simbol tersebut dapat dibuat dalam kata-kata, gambar, diagram, grafik, simulasi computer, persamaan matematika dan lain-lain.dengan menggunakan berbagai representasi, siswa dapat membuat hubungan, membandingkan, mengembangkan dan memperdalam pemahaman mereka tentang konsep matematika. Representasi matematis diperlukan untuk memecahkan masalah.

Dari beberapa pemaparan diatas, dapat disimpulkan bahwa kemampuan representasi siswa adalah kemampuan seseorang untuk menyajikan gagasan matematika yang meliputi penerjemahan masalah atau ide-ide matematis ke dalam interpretasi berupa bentuk gambar, persamaan matematis, maupun kata-kata.

Setiap kemampuan matematis mempunyai indikator masing-masing untuk dijadikan acuan keberhasilan dalam suatu penelitian. Adapun indikator dari kemampuan representasi matematis menurut NCTM (2003, hlm. 2) adalah sebagai berikut:

(1) Use representations to model and interpret physical, social,and mathematical phenomena, 
create and use representations to organize, record, and communicate mathematical ideas, and (3) select, apply, and translate among mathematical representations to slove problems

Dari pemaparan di atas dapat dijelaskan bahwa indikator kemampuan representasi matematis diantaranya (1) menggunakan representasi (verbal, simbolik dan visual) untuk memodelkan dan menafsirkan fenomena fisik, sosial, dan matematika, (2) membuat dan menggunakan representasi (verbal, simbolik dan visual) untuk mengatur, mengkomunikasikan ide-ide matematika, dan (3) memilih, menerapkan, dan menerjemahkan representasi (verbal, simbolik dan visual) matematika untuk memecahkan masalah.

Dalam penelitian ini, peneliti menggunakan indikator kemampuan representasi siswa yang lebih spesifik dan terukur, dengan rincian indikator sebagai berikut :

a. Representasi visual, yaitu:

1) Membuat representasi visual (gambar) dari sebuah masalah matematis

2) Mengubah representasi simbolik ke dalam representasi visual (gambar) dari sebuah masalah matematis

b. Representasi simbolik (persamaan atau ekspresi matematis), yaitu:

1) Membuat representasi simbolik untuk memperjelas dan menyelesaikan masalah matematis

2) Mengubah representasi visual (gambar) ke dalam representasi simbolik dari sebuah masalah matematis

c. Representasi verbal (kata-kata atau teks tertulis), yaitu:

Menyusun cerita yang sesuai dengan representasi yang disajikan.

\section{Metode Penelitian}

Jenis penelitian yang digunakan adalah jenis penelitian tindakan kelas (classroom action research). Desain penelitian yang digunakan dalam penelitian tindakan kelas ini adalah Kemmis dan Taggart yaitu sistem spiral refleksi diri yang dimulai dengan rencana, tindakan, pengamatan, refleksi, perencanaan kembali merupakan dasar untuk suatu ancangancang pemecahan permasalahan (Kasbolah, 1998/1999, hlm. 113). Pada setiap siklus mempunyai empat tahap yaitu:
a. Perencanaan (plan)
b. Tindakan (act)
c. Pengamatan (observe)
d. Refleksi (reflect)

\section{Pembahasan}

Pelaksanaan penelitian tindakan kelas disesuaikan dengan waktu yang telah dijadwalkan.Penelitian pun dilaksanakan sesuai dengan hari di mana terdapat mata pelajaran matematika yaitu hari Selasa $(3 \times 35$ menit) dan hari Rabu ( 2 x 35 menit).

Berdasarkan hasil analisis ditemukan bahwa pada deskripsi awal pembelajaran atau pra siklus sebelum menerapkan pendekatan matematika realistik, jika dibandingkan dengan batas kelulusan yang telah ditentukan yaitu dengan nilai $\geq 65$, kemampuan representasi matematis siswa masih berada dalam tingkatan rendah, hanya 9 orang siswa $(23.7 \%)$ telah lulus, sedangkan 29 orang siswa (76.3\%) berada dalam kategori belum lulus. Sedangkan rata-rata kelas yang diperoleh berada dalam kategori kurang yaitu sebesar 50.32 .

Selama proses pembelajaran dengan menerapkan pendekatan matematika realistik pada pembelajaran maetmatika pokok bahasan pecahan, menunjukkan aktivitas siswa jauh berbeda dengan pembelajaran sebelum menerapkan pendekatan matematika realistik. Dengan menerapkan pendekatan matematika realistik kegiatan pembelajaran menjadi lebih menyenangkan, siswa lebih aktif dalam bertanya, menjawab pertanyaan guru, berdiskusi dalam memecahkan 
masalah kontekstual yang tedapat pada Lembar Kerja Siswa (LKS) dengan menggunakan media maupun alat peraga, serta mempresentasikan hasil diskusi. Siswa dibagi ke dalam 6 kelompok, yaitu kelompok biru, merah, hijau, oren, kuning, dan ungu.

Peningkatan aktivitas siswa selama pembelajaran pada saat penerapan pendekatan matematika realistik dilihat dari perubahan pada siklus 1 maupun siklus 2. Pada siklus 1 aktivitas siswa dalam proses pembelajaran mencapai $50.6 \%$. Siswa dalam kelompok begitu antusias dan aktif dalam memecahkan masalah kontekstual yang berkaitan dengan indikator kemampuan representasi matematis.Alat peraga dan media yang digunakan adalah tempat kue ulang tahun, bolu coklat, penggaris yang berfungsi sebagai pisau dan kertas origami.

Pada siklus 2 aktivitas siswa dalam kelompok semakin meningkat dari siklus 1. Pada siklus 2 guru menggunakan media yang lebih menarik yaitu permen yuppy berbentuk pizza, plastisin dan kertas fraction strips. Setiap kelompok antusias dan aktif menggunakan media tersebut untuk memecahkan masalah kontekstual pada LKS.

Berikut tabel hasil pengamatan aktivitas siswa selama proses pembelajaran menggunakan penerapan pendekatan matematika realistik:

Tabel 1 Rekapitulasi Persentase Aktivitas Siswa pada Siklus 1 dan 2

\begin{tabular}{|l|c|c|c|}
\hline \multicolumn{1}{|c|}{$\begin{array}{c}\text { Aspek } \\
\text { Pengamatan }\end{array}$} & Siklus 1 & $\begin{array}{c}\text { Siklus } \\
\mathbf{2}\end{array}$ & Keterangan \\
\hline $\begin{array}{l}\text { Memahami } \\
\text { Masalah } \\
\text { Kontekstual }\end{array}$ & $50 \%$ & $83.33 \%$ & Meningkat \\
\hline $\begin{array}{l}\text { Menjelaskan } \\
\text { Masalah } \\
\text { Kontekstual }\end{array}$ & $52.08 \%$ & $89.58 \%$ & Meningkat \\
\hline $\begin{array}{l}\text { Menyelesaikan } \\
\text { Masalah } \\
\text { Kontekstual }\end{array}$ & $51.79 \%$ & $80.95 \%$ & Meningkat \\
\hline $\begin{array}{l}\text { Membandingkan } \\
\text { Jawaban }\end{array}$ & $41.67 \%$ & $83.33 \%$ & Meningkat \\
\hline Menyimpulkan & $52.08 \%$ & $81.25 \%$ & Meningkat \\
\hline
\end{tabular}

\begin{tabular}{|c|c|c|c|}
\hline $\begin{array}{c}\text { Aspek } \\
\text { Pengamatan }\end{array}$ & Siklus 1 & $\begin{array}{c}\text { Siklus } \\
\mathbf{2}\end{array}$ & Keterangan \\
\hline Rata-rata & $50.6 \%$ & $84.2 \%$ & Meningkat \\
\hline
\end{tabular}

Berdasarkan Tabel di atas, terlihat bahwa aktivitas siswa dalam pembelajaran pada setiap aspek pendekatan matematika realistik mengalami peningkatan.

Sedangkan untuk mengetahui peningkatan setiap indikator kemampuan representasi matematis siswa pada siklus 1 maupun 2 dapat dilihat pada tabel di bawah ini.

Tabel 2

\section{Rata-rata Presentasi Tingkat Kemampuan Representasi Matematis Siswa}

\begin{tabular}{|c|c|c|}
\hline \multirow{2}{*}{$\begin{array}{c}\text { Tingkat Kemampuan } \\
\text { Representasi } \\
\text { Matematis Siswa }\end{array}$} & \multicolumn{2}{|c|}{ Pelaksanaan Tindakan } \\
\hline & Siklus 1 & Siklus 2 \\
\hline $\begin{array}{l}\text { Representasi Visual } \\
\text { (gambar) }\end{array}$ & $75.44 \%$ & $86.62 \%$ \\
\hline $\begin{array}{l}\text { Representasi Simbolik } \\
\text { (persamaan atau } \\
\text { ekspresi matematis) }\end{array}$ & $53.29 \%$ & $73.03 \%$ \\
\hline $\begin{array}{l}\text { Representasi Verbal } \\
\text { (kata-kata atau teks } \\
\text { tertulis) }\end{array}$ & $53.95 \%$ & $71.71 \%$ \\
\hline
\end{tabular}

Dari Tabel di atas dapat dilihat bahwa kemampuan representasi visual siswa secara keseluruhan mengalami peningkatan.Kemampuan representasi visual dari $75.44 \%$ pada siklus 1 meningkat menjadi $86.62 \%$ pada siklus 2.Sedangkan kemampuan representasi simbolik dari 53.29\% meningkat menjadi $73.03 \%$ pada siklus 2.Pada siklus 1, kemampuan representasi verbal siswa sebesar 53.95\% meningkat menjadi $71.71 \%$ pada siklus 2.

Pada siklus 1 maupun siklus 2 terjadi peningkatan tingkat kemampuan representasi matematis siswa. Tabel berikut menyajikan tingkat kemampuan representasi matematis siswa pada data awal sampai dengan siklus 2 , 
Tabel 3

Presentase Kriteria Tingkat Kemampuan Representasi Matematis

\begin{tabular}{|c|c|c|c|c|c|c|}
\hline \multirow[b]{2}{*}{$\begin{array}{c}\text { Krite } \\
\text { ria }\end{array}$} & \multicolumn{2}{|c|}{ Data Awal } & \multicolumn{2}{|c|}{ Siklus 1} & \multicolumn{2}{|c|}{ Siklus 2} \\
\hline & $\begin{array}{c}\text { Frekue } \\
\text { nsi } \\
\text { (f) } \\
\end{array}$ & $\begin{array}{c}\text { Presen } \\
\text { tase } \\
(\%) \\
\end{array}$ & $\begin{array}{c}\text { Frekue } \\
\text { nsi (f) }\end{array}$ & $\begin{array}{c}\text { Presen } \\
\text { tase } \\
(\%)\end{array}$ & $\begin{array}{c}\text { Frekue } \\
\text { nsi (f) }\end{array}$ & $\begin{array}{c}\text { Presen } \\
\text { tase } \\
(\%)\end{array}$ \\
\hline A & 0 & 0 & 4 & 10.53 & 8 & 21.05 \\
\hline B & 3 & 7.89 & 11 & 28.95 & 20 & 52.63 \\
\hline C & 9 & 23.68 & 12 & 31.58 & 7 & 18.42 \\
\hline $\mathrm{D}$ & 21 & 55.26 & 8 & 21.05 & 3 & 7.89 \\
\hline$E$ & 5 & 13.16 & 3 & 7.89 & 0 & 0 \\
\hline
\end{tabular}

disimpulkan bahwa terdapat peningkatan pada kemampuan representasi matematis siswa, hal ini terlihat pada kriteria A (Amat Baik), B (Baik), dan C (Cukup) mengalami peningkatan frekuensi dari data awal hingga siklus 2. Sedangkan kriteria D (Kurang) dan E (Sangat Kurang) mengalami penurunan frekuensi sehingga dapat dikatakan penelitian dengan menggunakan pendekatan matematika realistik ini dapat meningkatkan kemampuan representasi matematis siswa.

Sedangkan untuk rekapitulasi ketuntasan belajar siswa tiap siklus ditunjukkan pada Tabel 4

Tabel 4 Persentase Kelulusan dan
Ketuntasan Belajar Siswa Tiap
Siklus
\begin{tabular}{|c|c|c|c|}
\hline & Tuntas & $\begin{array}{l}\text { Belum } \\
\text { Tuntas }\end{array}$ & $\begin{array}{c}\text { Jumlah } \\
\text { Kelulusan }\end{array}$ \\
\hline $\begin{array}{c}\text { Data } \\
\text { Awal }\end{array}$ & $23.7 \%$ & $76.3 \%$ & 9 orang \\
\hline $\begin{array}{c}\text { Siklus } \\
\text { I }\end{array}$ & $57.9 \%$ & $42.1 \%$ & 22 orang \\
\hline $\begin{array}{c}\text { Siklus } \\
\text { II }\end{array}$ & $89.5 \%$ & $10.5 \%$ & 34 orang \\
\hline
\end{tabular}

Berdasarkan ketentuan nilai ketuntasan yaitu $\geq 65$, maka dapat diketahui bahwa dari 38 siswa hanya ada 9 siswa yang tuntas belajar secara individual atau sebanyak $23.7 \%$, sedangkan 29 siswa lainnya atau sebanyak $76.3 \%$ termasuk kedalam kategori belum tuntas dan dengan nilai rata-rata yang diperoleh siswa secara klasikal adalah 50.32, sehingga hal ini memerlukan suatu tindakan perbaikan agar presentase ketuntasan dapat meningkat dan nilai rata-rata siswa juga berada di atas kriteria ketuntasan minimal. Adapun setelah dilakukan tindakan perbaikan pada pelaksanakan tindakan siklus 1, dapat terlihat perubahan antara ketuntasan belajar di data awal dengan ketuntasan belajar di siklus 1, hal ini terbukti dari 38 siswa, ada 22 siswa yang termasuk kategori tuntas atau sebanyak $57.9 \%$ sedangkan 16 siswa lainnya atau sebanyak $42.1 \%$ masih berada pada kategori belum tuntas. Nilai rata-rata siklus 1 adalah 64.21 dengan kategori cukup.Persentase siswa yang tuntas pada siklus 1 masih belum mencapai ketuntasan secara klasikal yang telah ditetapkan, maka dilakukan perbaikan pada siklus 2. Ketuntasan belajar pada siklus 2 mencapai $89.5 \%$ atau sebanyak 34 siswa sedangkan 4 siswa atau sebanyak $10.5 \%$ belum tuntas. Untuk nilai rata-rata mengalami peningkatan menjadi 80.29 dengan kategori baik.

Secara jelas peningkatan presentase ketuntasan belajar siswa dapat terlihat pada gambar diagram berikut: 


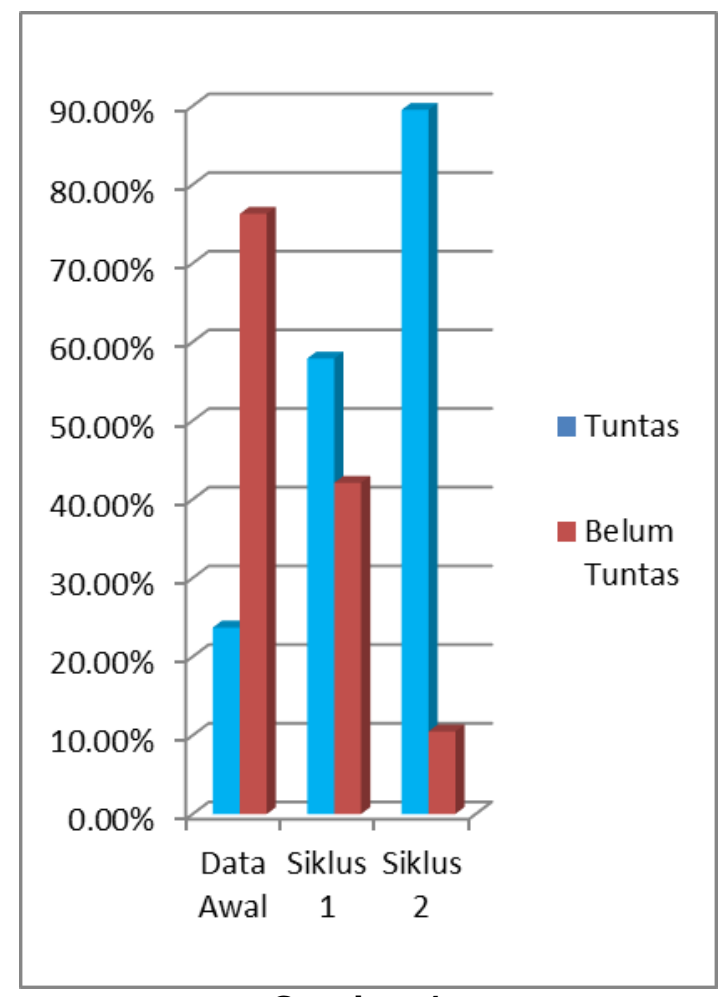

Gambar 1
Diagram Batang Ketuntasan Belajar
Siswa

\section{E. Kesimpulan}

Berdasarkan hasil penelitian yang dilakukan terhadap siswa kelas IV SDN 17 Nagri Kaler, dapat diambil kesimpulan sebagai berikut:

1. Aktivitas belajar siswa ketika pembelajaran

menggunakan pendekatan matematika realistik terjadi peningkatan dari siklus 1 ke siklus 2 berdasarkan hasil observasi. Peningkatan tersebut dapat diuraikan sebagai berikut: memahami masalah kontekstual pada siklus 1 sebesar $50 \%$ meningkat menjadi $83.33 \%$ pada siklus 2 dengan kategori sangat tinggi. Menjelaskan masalah kontekstual pada siklus 1 sebesar $52.08 \%$ menjadi $89.58 \%$ dengan kategori sangat tinggi. Menyelesaikan masalah kontekstual pada siklus 1 sebesar $51.79 \%$ meningkat menjadi $80.95 \%$ dengan kategori sangat tinggi.
Membandingkan jawaban pada siklus 1 sebesar $41.67 \%$ menjadi $83.33 \%$ dengan kategori sangat tinggi. Menyimpulkan pada siklus 1 sebesar $52.08 \%$ menjadi $81.25 \%$ pada siklus 2 dengan kategori sangat tinggi.

2. Setelah diterapkan pembelajaran matematika dengan pendekatan matematika realistik terjadi peningkatan kemampuan representasi matematis siswa kelas IV SDN 17 Nagri Kaler. Hal ini terlihat dari siswa yang tuntas secara klasikal pada siklus 1 sebanyak 22 orang (57.9\%) dengan meningkat menjadi 34 orang (89.5\%) pada siklus 2. Untuk setiap indikator kemampuan representasi mengalami peningkatan yaitu kemampuan representasi visual dari $75.44 \%$ pada siklus 1 meningkat menjadi $73.03 \%$ dengan kategori cukup pada siklus 2. Pada siklus 1 , kemampuan representasi verbal siswa sebesar $53.95 \%$ meningkat menjadi $71.71 \%$ dengan kategori cukup pada siklus 2 .

\section{Daftar Rujukan}

Adhar, L. (2012). Pembelajaran matematika dengan metode penemuan terbimbing untuk meningkatkan kemampuan representasi dan pemecahan masalah matematis siswa SMP.Jurnal Pendidikan Penelitian Pendidikan UPI. 13(2), hlm.1-10.

Amalia, R. (2013). Pendekatan pengajuan masalah secara berkelompok untuk meningkatkan kemampuan representasi visual matematik siswa SMP.(Skripsi).Universitas Pendidikan Indonesia. Bandung.

Arifin, Z. (2010). Evaluasi pembelajaran.Bandung: $\quad \mathrm{PT}$. Remaja Rosdakarya.

Arikunto, S. (2009). Manajemen penelitian. Jakarta: PT Rineka Cipta. 
(2012). Penelitian tindakan kelas. Jakarta: PT. Bumi Aksara

(2013). Prosedur Penelitian suatupendekatan praktik. Jakarta: PT. Rineka Cipta.

Dahar, R.W. (2011).Teori-teori belajar \& pembelajaran. Bandung: Erlangga.

Effendi, L. A. (2012). Pembelajaran matematika dengan metode penemuan terbimbing untuk meningkatkan kemampuan representasi dan pemecahan masalah matematis siswa SMP. Jurnal Universitas Pendidikan Indonesia (online). Tersedia di: http://jurnal.upi.edu/file/6 Leo A dhar Effendi Pdf. Diakses 31 Oktober 2013.

Fitriana, H. (2010). Pengaruh pendekatan pendidikan matematika realistik terhadap kemampuan pemecahan masalah matematika (Skripsi) Fakultas IImu Tarbiyah dan Keguruan, Universitas Islam Negeri Syarif Hidayatullah, Jakarta.[Online]. Tersedia di: http://repository.uinjkt.ac.id/dspa ce/bitstream/123456789/1047/1/ 98042-HANNY\%20FITRIANAFITK.pdf . Diakses 15 November 2013.

Goldin, A.G. (2002). Representation in mathematical learning and problem solving.Dalam Handbook of International Research in Mathematics Education editor Lyn D English. New Jersey: Lawrence Erlbaum Associates, Inc.

Gravemeijer, K.P.E. (1991). Developing realist mathematics education.Utrecht: Freudenthal Institut. Netherland.

Hermawan, R. dkk.(2007). MetodePenelitian Pendidikan Sekolah Dasar. Bandung: UPI Press.

Heruman.(2008). Model pembelajaran matematika di sekolah dasar.
Bandung: PT. Remaja Rosda Karya.

Hudiono, B. (2008). Peran pembelajaran diskursus terhadap pengembangan daya representasi. Bandung: UPI Press. 32 (4), hlm. 16.

Hudojo, H. (1988). Mengajar belajar matematika. LPTK Depdikbud: Jakarta.

Hwang, dkk.(2007). Multiple representation skills and creativity effects on mathematical problem solving using a multimedia whiteboard system educational technology \& society, 10 (2), hlm.191-212 [Online]. Tersedia di :http://www.ifets.info/journals/10 2/17.pdf. Diakses 17 November2013.

Johnson, T \& Huge,N. (2010). Swadidik matematika. Bandung: Pakar Raya.

Kalathil, R.R., \& Sherin, M.G. (2000).Role of Students' representation in the mathematics classroom.In $B$. dalam Fishman \& S. o'ConnorDivelbiss (Eds), Fourth International Conference of the Learning Sciences (pp.27-28). Mahwah, NJ: Eribaum. [Online]. Tersedia di: http://www.uimch.edu/ icls/proc eedings.pdf/Kalathil.pdf.

Kartini.(2009). Peran representasi dalam pembelajaran matematika.Jurnal pada Seminar Nasional Matematika dan Pendidikan Matematika Jurusan Pendidikan Matematika FMIPA UNY 5 Desember 2009. [Online] tersedia di: http://eprimts.uny.ac.id/P22-

$\begin{array}{lll}\text { Kartini.pdf. Diakses } & 17\end{array}$ November 2013.

Kasbolah, K. (1998/1999). Penelitian tindakan kelas (PTK).Malang: Depdikbud.

Kusumah, W \& Dedi, D. (2012). Mengenal penelitian tindakan kelas.Jakarta: PT. Indeks. 
Kunandar.(2009).

Langkahmudahpenelitiantindaka nkelassebagaipengembanganpr ofesi guru. Jakarta: PT. Raja Grafindo Persada.

Lestari, P. A. (2014). Penerapan pendekatan matematika realistik untuk meningkatkan kemampuan penalaran matematik siswa. (Skripsi) FIP Jurusan PGSD UPI Kampus Purwakarta.

Minggono, dkk. (2013). Kemampuan representasi matematis siswa dalam pertidaksamaan pecahan di kelas $X$ SMA.[Online]. Tersedia di: http://jurnal.untan.ac.id/index.ph p/ipdpb/article/viewFile/1378/pdf . Diakses 15 November 2013.

Mozez, L.Y. (2008). Kemampuan representasi matematis siswa kelas IV SD melalui pendidikan matematika realistik pada konsep pecahan dan konsep pecahan senilai.(Tesis) Jurusan Pendidikan Matematika dan IImu Pengetahuan Alam, Program Studi Pendidikan Matematika Sekolah Dasar, Program Pascasarjana, Universitas Negeri Malang.

Mudzakkir, H. S. (2006). Strategi pembelajaran "Think-Talk-Write" untuk meningkatkan kemampuan representasi matematik beragam siswa SMP.Tesis.Sekolah

Pascasarjana, Universitas Pendidikan Indonesia Bandung: [Online].Tersedia di http://repository.upi.edu, di akses 16 November 2013/

Mulyasa, E. (2006). Kurikulum yang disempurnakan.Bandung: PT. Remaja Rosdakarya.

Mulyasa, E. (2009). Praktik penelitian tindakan kelas. Bandung: PT. Remaja Rosdakarya.

NCTM. (2000). Using the NCTM 2000 principles and standards with the learning from assements materials. [Online]. Tersedia di:
http://www.wested.org/lfa/NCTM 2000.PDF. Diakses 16 November 2013. .(2003). Principles and Standars for School Mathematics. Reston VA : The National Council of Teachers of Matematics Inc . (2003). Program for intial reperation of mathematics specialists.[Online]. Tersedia di: http://www.ncate.org/LinkClick.a spx?fileticket=\%2Frfx5Ju56RY \%3D\&TABID=676. Diakses 15 November 2013.

Nurroeni, C. (2013).

Shoimin, A. (2013). 68 model pembelajaran inovatif dalam kurikulum 2013. Yogyakarta : AR-RUZZ MEDIA.

\section{Riwayat Penulis}

Misel adalah sarjana pendidikan dalam bidang Pendidikan Guru Sekolah Dasar yang didapatnya setelah menyelesaikan studi di UPI Kampus Purwakarta. Erna Suwangsih adalah dosen UPI Kampus Purwakarta, menyandang gelar megister pendidikan dalam bidang pendidikan matematika yang didapatnya setelah menyelesaikan S-2 di UPI. Alamat yang bisa dihubungi UPI Kampus Purwakarta Jl. Veteran Nomor 8. 